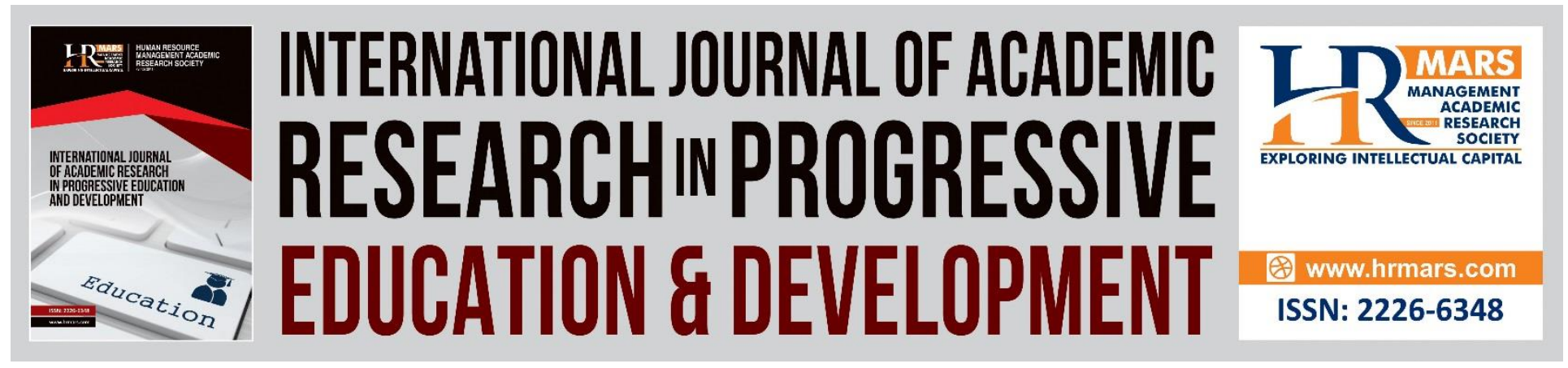

\title{
Educational Strategies on Memorizing the Quran: A Review of Literature
}

\author{
N. Hashimah A. Shukri, M. Khalid M. Nasir \& Khadijah Abdul Razak
}

To Link this Article: http://dx.doi.org/10.6007/IJARPED/v9-i2/7649

DOI:10.6007/IJARPED/v9-i2/7649

Received: 10 May 2020, Revised: 30 May 2020, Accepted: 24 June 2020

Published Online: 27 July 2020

In-Text Citation: (Shukri, Nasir, \& Abdul Razak, 2020)

To Cite this Article: Shukri, N. H. A., Nasir, M. K. M., \& Razak, K. A. (2020). Educational Strategies on Memorizing the Quran: A Review of Literature. International Journal of Academic Research in Progressive Education \& Development. 9(2), 632-648.

Copyright: (C) 2020 The Author(s)

Published by Human Resource Management Academic Research Society (www.hrmars.com)

This article is published under the Creative Commons Attribution (CC BY 4.0) license. Anyone may reproduce, distribute, translate and create derivative works of this article (for both commercial and non-commercial purposes), subject to full attribution to the original publication and authors. The full terms of this license may be seen

at: http://creativecommons.org/licences/by/4.0/legalcode

\section{Vol. 9(2) 2020, Pg. 632 - 648}

Full Terms \& Conditions of access and use can be found at http://hrmars.com/index.php/pages/detail/publication-ethics 


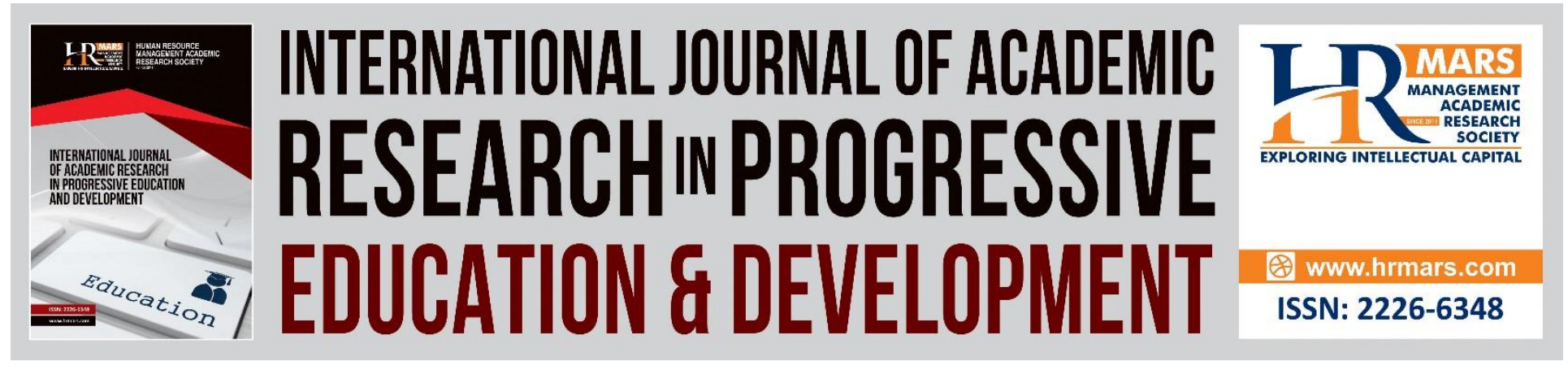

\title{
Educational Strategies on Memorizing the Quran: A Review of Literature
}

\author{
N. Hashimah A. Shukri, M. Khalid M. Nasir \& \\ Khadijah Abdul Razak
}

Faculty of Education, Universiti Kebangsaan Malaysia (UKM)

Email: nhashimahashukri@gmail.com,mdkhalid@ukm.edu.my,khadijah.razak@ukm.edu.my

\begin{abstract}
Quran memorization is not a new practice but a continuation from the practice of Prophet Muhammad SAW and maintaining the memorization of the Quran is a huge responsibility as it requires enormous effort and discipline. The lack of knowledge, memory strategies and effective methods in memorizing the Quran could deteriorate the performance of the memory. This study aims to explore the specific memory strategies in Quran memorization. A review of literature was conducted on the journal articles between the year 2015 to 2020 through library sources in accessing websites like Web of Science Database, Scopus Database, Science Direct, SAGE Journal and Wiley Online Library. The analysis found that studies related to memory strategies are mainly experimental across the field of neuroscience, medical and linguistics while not many in the field of Islamic education. This review explains and outlines eight educational strategies in memorizing the Quran involving the internal and external strategies: attention to Quranic verses either verbally or visually, repetition, understanding, organizing, exercise, balanced diet, sufficient sleep and memory aids especially in the application of technology. This review is hoped to guide the students and teachers in improving their Quran memorization as well as positively influence the memory performance.
\end{abstract}

Keywords: Quran, Memorization, Memory Strategies, Recitation, Neuroscience.

\section{Introduction}

The Holy Quran is an ultimate basis for immense inspiration, guidance and wisdom in Islam and it is meant to be read, internalized the meaning as well as memorized. The Quran has 114 chapters (surahs) of over 6,000 verses (ayahs) which were divinely revealed word by word in stages to the Prophet Muhammad SAW by Allah through the Angel Gibraeel AS (610-632 A.D) (Abdullah et al., 2018). The Quran is also referred as the main source and guidance for all mankind as well as the source of knowledge and human life aspect, (Abdullah et al., 2018). Abdullah et al. (2018) also stated that the Prophet Muhammad SAW is perceived as "Sayyid al-Huffaz" or "Awwal Jumma" which refers to the first man in memorizing the Quran in the history of Islam. Besides, Arif (2005) in refuting the ideology of Orientalism dan Luxenberg emphasized that the Quran is 
proven to be undisputedly authentic as the principle of its authenticity does not constitute from the writing, instead from the consistency of the transmission from the revelation and direct teachings of chained narrations from Prophet Muhammad's SAW memorization and verbal readings. The compilation of the written Quran into a Mushaf by a committee of experts during the reign of Khalifah Uthman r.a was done to ensure the authenticity and standardization of the Quran which was based on the first-hand narration and mutawatir memorization from the Prophet (Arif, 2005).

Aziz et al. (2019) explained that memorization involves the process of remembering and preserving 30 juzu' of the Quran by mastering specific memorizing skills and adhering to the specific rules of memorization. Quran memorization refers to the action of memorizing every verse of the Quran which should be accompanied with the pure intention in preserving the Quran verses from any alterations either in the form of addition, elimination or manipulation of the verses. Quran memorization is not an easy practice as evident in the study by Islamic Education Division, Ministry of Education (MOE) Malaysia in 2018 in Yusuf et al. (2019) as the MOE found a high percentage of students who were unable to memorize the Quran within the time allocated while only $63 \%$ of students in National Religious Secondary Schools (SMKA) and Fully Residential School (SBP) have succeeded to memorize the Quran within the duration of five years. In addition, memory is crucial in the process of knowledge acquisition and as the memory system is made of brain tissue, the memory performance could possibly be affected by the state of the brain apart from poor health, fatigue and nutritional deficiency (Herrmann et al., 2002). However, Herrmann et al. (2002) further explained that there are a few information modes which could enhance the ability in memorization which includes mental manipulation involving repetitive act of thinking of words and images, manipulations of physical environment which requires physical record, other stimulus or cueing retrieval in retrieving the information as well as social manipulation through the stimulation of behavior and conversation.

The Quran does not only serve as the guidance in life, in fact its people are also blessed by Allah SWT as stated in the hadith (2016: 180: 989) by An-Nawwas bin Sam'an r.a., he reported: "I heard the Messenger of Allah saying, "The Quran and its people who applied it, will be brought on the Day of Resurrection preceded with Surat Al-Baqarah and Surat Al-"Imran arguing on behalf of those who applied them."

This hadith is an argument for the safety of its people who read, think and practice the Quran. It is clear that the responsibility towards the Quran does not only involve memorization, but must also include recitation with tajweed (rules of recitation) as well as understanding the meaning of verses in order to benefit the life of its people. Therefore, the objectives of this paper are:

- to review several memory strategies of Quran memorization such as attention, rehearsal, repetition and chunking.

- to discuss the effectiveness of those strategies.

\section{Focus of the Review}

This review focuses on the educational strategies in improving the memory, specifically in memorizing the Quran. In general, memorization involves a process called basic cognitive process which includes coding, storing and recalling the memory as this process occurs in the multiple 
memory systems which function differently but interconnected (May \& Einstein, 2013; Herrmann et al., 2002); sensory memory, working memory (short-term memory) and long-term memory based on the Information-Processing Model of Memory (Banikowski \& Mehring, 1999). Sensory memory is a memory system which records the information received through the senses by receptor cells before the information being screened and selected to be processed in the next stage of memory, (May \& Einstein, 2013; Banikowski \& Mehring, 1999). Meanwhile, working memory (WM) is a short-term memory whereby the new information received will be processed mentally which includes understanding and problem solving. For long-term memory (semantic memory), it is a component which is capable in storing information for a long period of time and could interconnect the information in the memory, (May \& Einstein, 2013; Banikowski \& Mehring, 1999). According to Banikowski and Mehring (1999), there are several factors which could cause the loss of information or memory loss; storage failure especially in the long-term memory, retrieval failure, time decay, insufficient attention, interference or inhibition, primacy and recency effects, and insufficient practice. Therefore, appropriate educational strategies were executed in order to maximize the function of the memory based on the study by May and Einstein (2013), the memory strategies involved for the sensory memory are attention and automaticity, maintenance rehearsal, as well as elaborative rehearsal and chunking for the working memory as to ensure that the information could be activated. However, this review only focuses on the memory strategies of classification, internal and external based on the studies by Lineweaver et al. (2018); Frankenmolen et al. (2018).

This study also assumes that the educational strategies in memorizing the Quran could positively impact the performance of the memory as evident in the study by Frankenmolen et al. (2018), which shows significant improvement on the memory performance of the intervention group based on the primary outcome measure on the memory functioning in daily life. This is also corroborated with the study by Lineweaver et al. (2018) that memory strategies had hugely affected the functions of daily memory based on the opinion of the adult respondents. Based on the past studies on classification memory strategies, this study solely focuses on the internal memory strategies which consist of attention, rehearsal, repetition and chunking as well as the external memory strategies which refer to memory aids, exercise, sufficient sleep and balanced diet as healthy lifestyle is crucial for a good mental state and memory (The State of Queensland, 2017). This study is conducted to answer the following research questions: (a) How does the capability of memory could be improved? (b) What are the educational strategies that could be used in memorizing the Quran?

\section{Methodology}

This study implements a descriptive literature review approach in exploring the educational strategies in memorizing the Quran. Two research methods are applied in collecting and analyzing the literature. First, the Google search engine is utilized as the main medium in accessing the indexed journal websites such as Web of Science Database, Scopus Database, Science Direct, Sage, Directory of Open Access Journals (DOAJ) and others. The keywords of memory and memory strategy are used to gather information related to memory strategies that it has led to limited findings on the keywords of remembering Quran. Therefore, specific keywords are then used; attention, rehearsal, repetition and chunking in searching for a more 
accurate information. Second, this study also visits a few websites of Islamic journals such as Quranica, Journal of Qur'anic Studies, Jurnal al-Turath and others in obtaining information related to memory strategies in Quran memorization. This study focuses on the literature between the year 2015 to 2020. Nevertheless, some indirect keywords are also used such as tajweed, technology, memorization system, tarannum and others.

\section{Findings}

Based on the review of literature conducted on the journals between the year 2015 to 2020 on memory strategies, majority of the studies are found to be experimental research especially in the year 2019 and 2020. Meanwhile, research on the Quran memorization are brought into the spotlight in the year 2015 and 2019. Relevant articles are gathered through Taylor \& Francis Online, Science Direct dan Directory of Open Access Journals (DOAJ) database. The general search in Taylor \& Francis Online database using the keyword memory found 108,239 results while 58,398 results for the keywords memory strategy, which led to the collection of 35 literature before screening. For the search in Science Direct database, 116,779 results are found for the keywords memory strategy. Using the same database, the keyword rehearsal has gathered 15 literature out of 4,115 results, nine literature out of 377,721 results for the keyword attention and 15 literature out of 6,416 results for chunking. Apart of that, seven literature out of 55,286 results are found in the database of Wiley Online Library while three literature out of 30 results are found in Elsevier.

Nevertheless, based on the screening on the literature found, only 25 literature are identified as relevant: 16 from Taylor \& Francis Online, 7 from Science Direct, 1 from Wiley Online Library and 1 from Elsevier. On the other hand, the search on the keywords memorizing Quran and Quran found 986 results in Taylor \& Francis Online, 73 results in Science Direct and 477 results in Wiley Online Library, however none of the articles is considered relevant to the context of this study. Therefore, the search then continues in other databases which found three relevant literature; three out of six in IEEE Xplore, one out of 22 in Human Resource Management Academic Research Society (HRMRS), two in Science Direct, six out of 22 Directory of Open Access Journals (DOAJ) and others. The search of the relevant literature between the year 2015 to 2020 is illustrated in Figure 1 and Figure 2 shows the review related to Quran memorization within the same year. The search of relevant literature related to Quran memorization between the year 2015 to 2020 is presented in Figure 2.

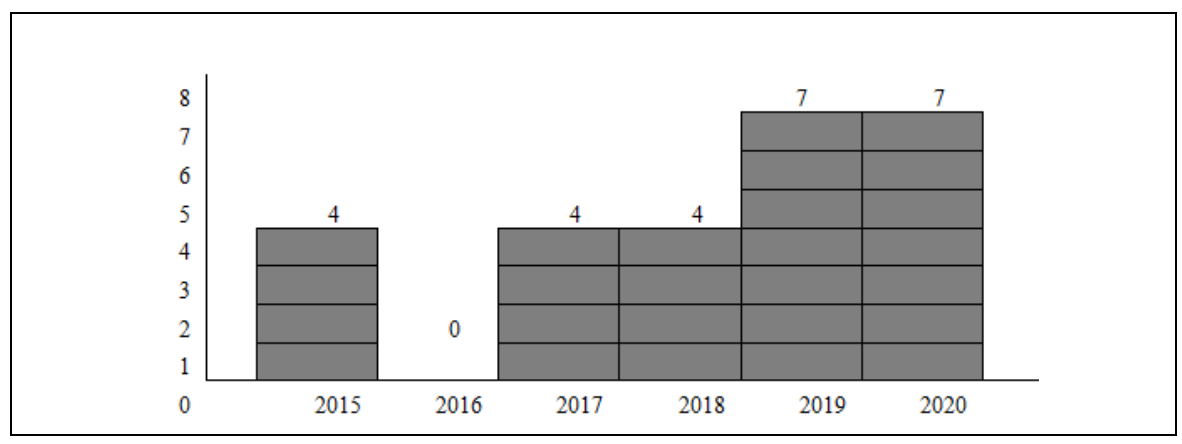

FIGURE 1. Literature related to memory strategies between the year 2015 to 2020 


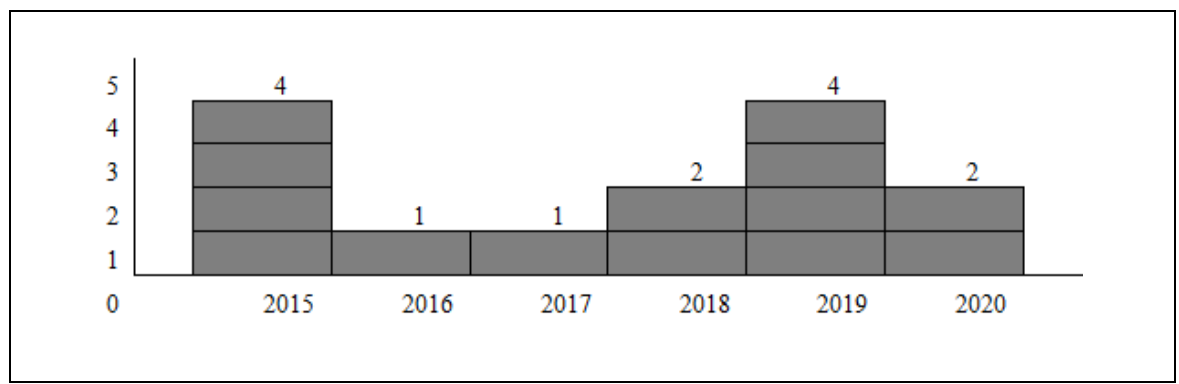

FIGURE 2. Literature related to Quran memorization between the year 2015 to 2020

\section{Research Design and Source of Publication}

The review of literature also analyzes the research design, field of study as well as prominent medium of publication. Studies related to memory are explored from various fields of knowledge including neuroscience, medical, psychology, education and others. The overall finding of literature review in this review is presented in Figure 3, in which 24 out of 40 relevant articles are experimental studies especially related to memory strategies, 14 are descriptive studies which are related to Quran memorization while another 2 articles are studies on the development of technology application on Quran memorization.

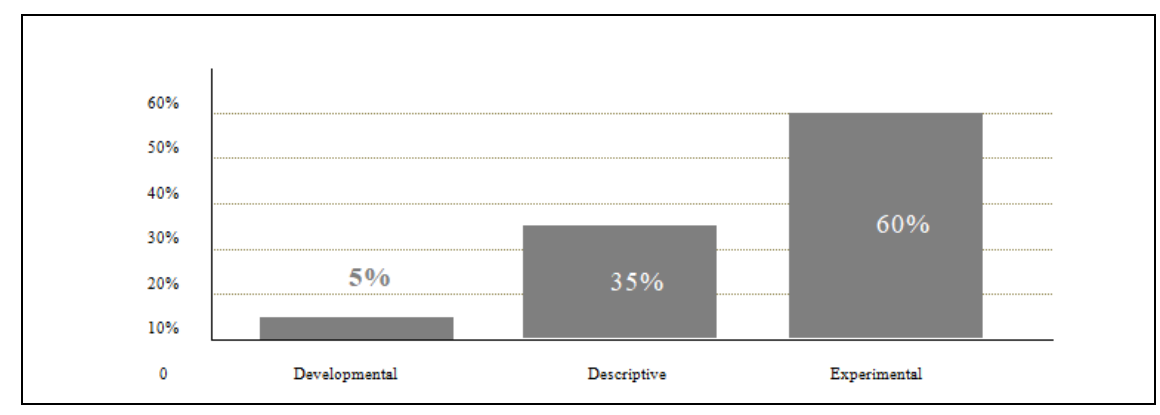

FIGURE 3. Literature related to research design

For the source of publication, majority of the literature is found in Taylor \& Francis Online database, which is 16 literatures, followed by Science Direct database with nine literatures, six from DOAJ and three from IEEE Xplore Digital Library while one relevant literature is found in HRMRS, Wiley Online Library and Elsevier respectively and another two from other journals as shown in Figure 4. 
Vol. 9, No. 2, 2020, E-ISSN: $2226-6348$ @ 2020 HRMARS

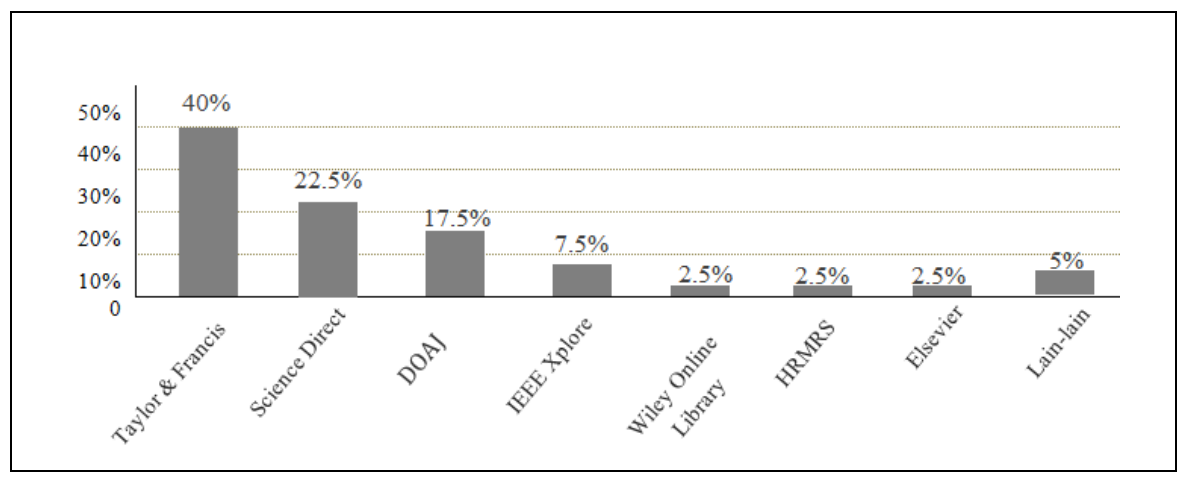

FIGURE 4. Literature related to source of publication

Research related to memory has gathered high attention in the field of neuroscience as 11 relevant literature are found, followed by nine literature respectively from the field of Islamic education and health science. Besides, research on memory strategies is also expanded with the discovery on literature related to technology approaches as well as psychology, child development, language and linguistics, and communication as shown in Figure 5. The review of the literature from various fields leads to the classification of two memory strategies; external and internal strategy is summarized in Figure 6.

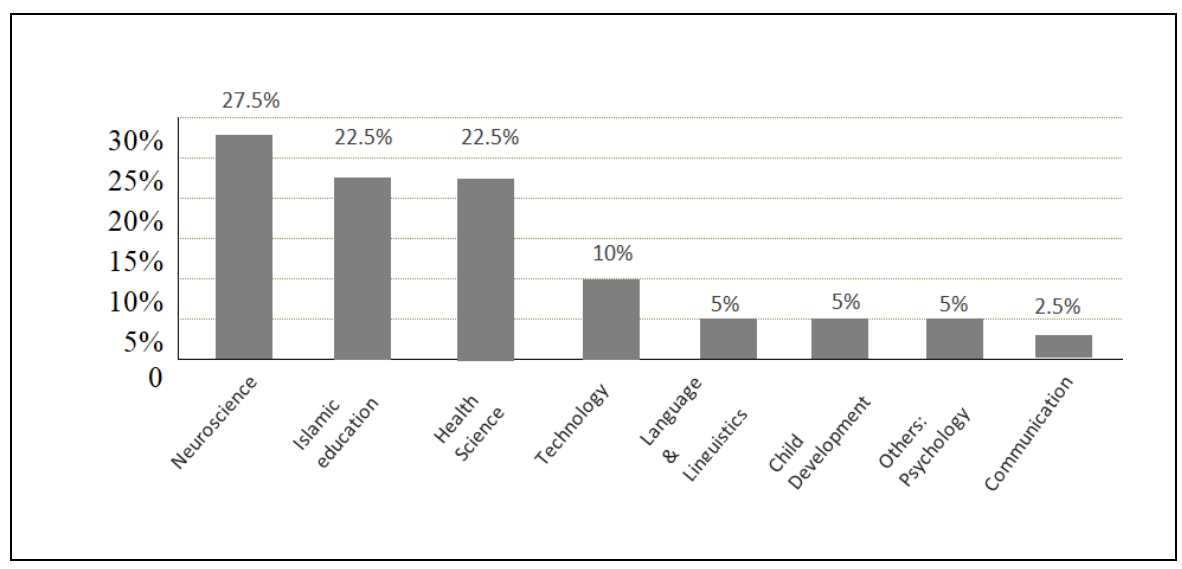

FIGURE 5. Literature related to field of study

\section{Outcome Types}

Apart from exploring the memory strategies, this study also examines the significance of the strategies, relevant strategies on Quran memorization as well as their effectiveness based on the past research. This finding is crucial as a guideline in improving the memory performance and quality of memorization which could then be applied in the teaching and learning of the Quran. The review of literature also discovers that there are number of studies on the effectiveness of memory strategies, which positively affected the memory performance (McCormick-Huhn et al., 2017) such as by physical training (Loprinzi et al., 2019) and effective sleep (Chen, 2019). 
Vol. 9, No. 2, 2020, E-ISSN: 2226-6348 @ 2020 HRMARS

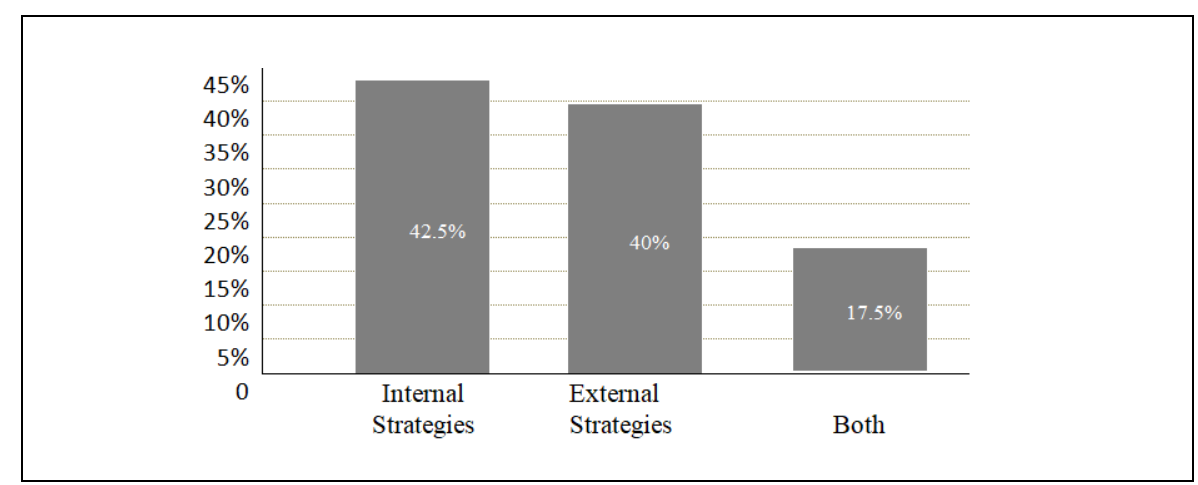

FIGURE 6. Literature based on the aspects of study (Classification of Memory Strategies)

Therefore, the discussion of the findings is based on the category of internal and external memory strategies as shown in Figure 6 in improving the performance of Quran memorization.

1) Internal memory strategy involves a process of mentally storing information in certain ways which includes repeating, counting, face-name associations, categorizing, mental visualization, or rhyming mnemonics, (Perna \& Perkey, 2016). This strategy is also used as a way to stimulate the recovery function of memory based on the supposition that any impaired memory will respond to mental exercise, (Perna \& Perkey, 2016). Besides, these memory strategies could also improve the memory performance through the improvement of encoding and retrieval. The internal memory strategies consist of:

i) Attention refers to the focus given to the information that are kept in the memory through visual sensory senses or auditory while avoiding any unprecedented distractions throughout the process of attention (Frankenmolen et al., 2018), which is crucial in ensuring the accuracy of the processed information in the next stage of memory.

ii) Repetition refers to the repetitive active practice towards certain information in a certain period time (Frankenmolen et al., 2018) and study by McCormickHuhn et al. (2017) proved that repetition is able to improve the memory retrieval ability as well as the ability to discriminate memory (the selection of relevant items) for adults.

iii) Rehearsal is the most frequently used in the field of education which requires specific skill and practice such as poem learning as this type of learning requires the skill of interpreting document and stories, (Herrmann et al., 2002). According to Herrmann et al. (2002) rehearsal is also known as mental manipulation as it involves repetitive act of thinking about oneself or certain significant matters.

iv) Associating refers to the act of making connection between new information with prior experience through the use of mnemonic or visual imagination and others (Frankenmolen et al., 2018).

v) Structuring or Chunking which involves the organization of information in accordance to certain criteria in a meaningful way which could enhance the ability of mind to process the information consecutively (Frankenmolen et al., 2018) such as arranging objects, planning future events and others. 
2) External memory strategy refers to the device which could help to balance the memory disturbance by reducing daily memory issues if it is used effectively such as technology, memory aids and others (Perna \& Perkey, 2016; The State of Queensland, 2017).

3) This review outlines eight memory strategies of internal and external strategies in Quran memorization:

i) Attention in memorizing the Quran refers to the emphasis given on the verses of the Quran either visually or auditorily which includes the reading with mus'haf (the written copy of the Quran), memorizing the verses aloud, repeating the verses until fluency is achieved before moving on to the next verses, reciting the verses fluently before memorizing, reciting the verses with others, reciting the verses properly with tajweed, reciting the memorized verses to others such as the teacher (Yaacob et al., 2019), listening the verses from the cassette, CD or MP3 before memorizing, writing the verses on paper before memorizing them as well as reciting the Quran by applying the tarannum and so on.

ii) Repetition in memorizing the Quran has various techniques depending on the rules of the teacher or oneself. Anwar (2019) explained that repetition of the Quran verses has three forms; repetition of new verses, repetition of old verses and overall repetition of the memorized verses. These repetitions could be done weekly and monthly regardless of places such as while waiting for bus, on the way to school, waiting for the time of prayer or during leisure period. These forms of repetition could be applied through silent repetition, in lower voice or aloud (Anwar, 2019). These techniques indirectly could train the mouth for accurate recitation and correct the wrong pronunciation especially on the makhroj and tajweed in order to ensure a quality memorization, (Anwar, 2019).

iii) These forms of repetition are also known in various terms in Othman method from Turkey such as Tekrar (simultaneous repetition), Chi (memorization of new verses), Zor Pismis (repetition of old memorization of the difficult verses), Kolay Pismis (repetition of old memorization of simple verses in a particular juz), Hepsi Tekrar Seyfa (repetition of memorization of all the pages in a particular juz), Has (repeat cycle technique for students who have completed the whole Quran) and Murojaah (repeated recitation) (Ariffin et al., 2016). Other forms of repetition which could be applied in memorizing the Quran are by reciting the verses in daily prayer, repeating the memorized verses according to the schedule and repeating the memorized verses in the middle of the night. Repetition plays a crucial role in the process of memorizing the Quran as Anwar (2019) emphasized that the higher the interaction and practice with the Quran, the higher the chance to memorize the Quran better which make the verses easier to be remembered and stored permanently in the long-term memory, hence eventually forms the ability to speak spontaneity.

iv) Understanding the meaning of the Quran through the concept of elaborative rehearsal and applying it in life. There are a few initiatives in understanding the meaning of Quran verses as recommended by Yaacob et al. (2019) which include scanning the meaning of the verses, learning the meaning according to the general themes as well as connecting the meaning with the sequence of the verses. Allah 
has firmly stated the truth of the Quran and asked the human being to think as proclaimed in Surah Ar-Ra'd verse 19:

"Then is he who knows that what has been revealed to you from your Lord is the truth like one who is blind? They will only be reminded who are people of understanding."

v) There are various techniques in organizing or chunking the Quran memorization which commonly depends on the daily memorization schedule or application of certain memorization systems decided by the teacher. Among the memorization systems applied in the tahfiz institutions in Malaysia are Othman method from Turkey, the method of Deobandy from India, the method of Panipati from Pakistan, method of Malwali from Bangladesh, method of Indonesia and the method from Saudi Arabia (Yaacob et al., 2019).

vi) The State of Queensland (2017) discusses that exercise could improve the blood circulation which carries additional oxygen and stimulate the growth of new brain cells. Studies by Loprinzi et al. (2019) involving the dance routine towards patients of Mild Cognitive Impairment ( $\mathrm{MCl}$ ) have shown improvement in memory performance and processing speed test as compared to the $\mathrm{MCl}$ patients who received the normal treatment. This result indicates that exercise should be applied as one of the memory strategies as it could benefit the cognitive function.

vii) Balanced diet is the main health factor which influences the cognitive state in the molecule system (Gómez-Pinilla, 2008). Thus, balanced diet should be given serious attention as one study by Abbott et al. (2019) found that both high-fat foods and sugar have proven to attenuate the memory.

viii) Sufficient sleep is very important to human especially for individuals of middle and older age should cover 7-8 hours in a day as it is crucial for the health of the brain as well as the memory (Chen, 2019).

ix) Memory aids have proven to benefit the memory performance as study by Jamieson et al. (2017) found that daily log book (77\%), checklist (78\%), calendar (79\%), mobile phone reminder (38\%) and alarm (38\%) are common memory aids used by respondents with brain injury. Technology plays such a crucial role in Quran learning especially in correcting the makhraj and tajweed in Quran memorization. This is supported by Aziz et al. (2019) that modern technology could contribute for better performance in memorization as compared to conventional method which later proposes this idea to the tahfiz institutions that they should be ready in revamping their teaching and learning system. In addition, there are other memory aids which could be used by students in improving their Quran memorization such as ITQAN (Almosallam et al., 2015), i-Tasmik (Musa et al., 2018) and TeBook (Abdullah et al., 2019). The use of the aforementioned memory aids does not only depend on the interest and creativity of the students, but also require continuous effort in order to ensure the goal of the memorization is achieved.

4) Based on the literature review conducted, technology was developed along with incorporating traditional memory aids for the specific purpose of Quran memorization. The 
Vol. 9, No. 2, 2020, E-ISSN: $2226-6348$ @ 2020 HRMARS

overall results of technology-related findings in memorizing the Quran are illustrated in Figure 7.

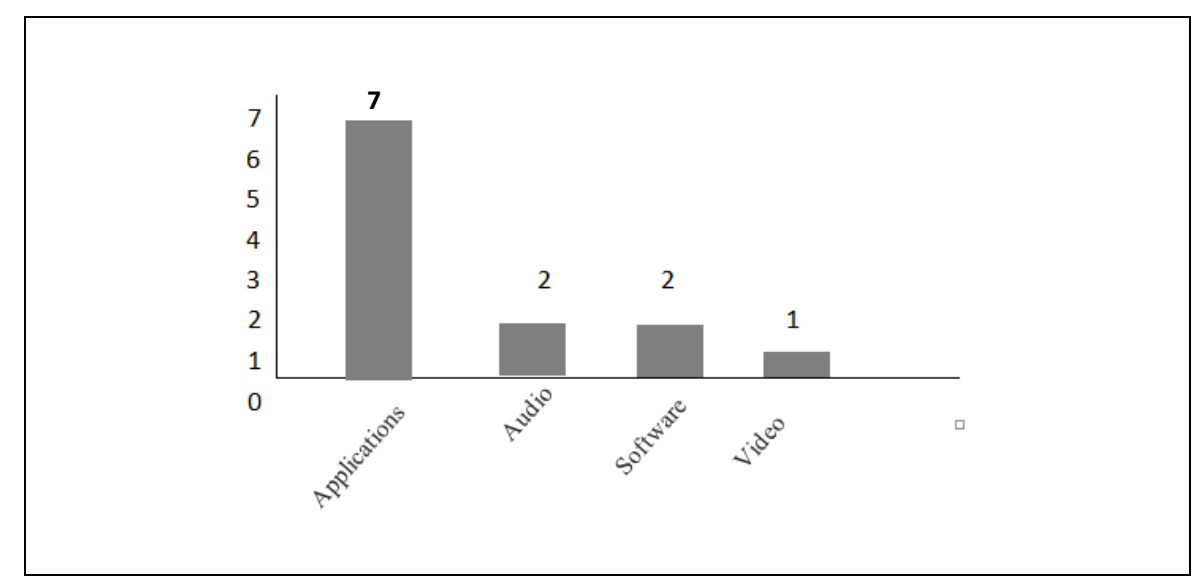

FIGURE 7. Type of technology for Quran memorization purpose

This review found that technology is viewed as a tool to improve Quranic skills including memorization as seven applications were discovered involving applications, two audio technologies, two software related technologies and one video related technology. Among the technologies developed are TeBook app (Abdullah et al., 2019) which has the advantage of assessing Quran recitation between readers and assessors and i-Tasmik application which evaluates Quran recitations and allows comments from teachers or parents (Musa et al., 2018). Another app is known as ITQAN, which helps in mastering memorization through topical interpretation with visual techniques such as mind map (Almosallam et al., 2015). The ability of this app is tested on twenty subjects from the "Dar Makah" and the result showed that $85 \%$ of the students agreed that this app is useful in memorization as well as able to boost their interest up to $80 \%$, (Almosallam et al., 2015).

Aziz et al. (2019) introduced the function of one mobile phone app in Quran memorization, e-Hafiz system which could assist in improving the skills of reciting and memorizing the Quran regardless of place and time, minimizing the recitation mistakes by comparing to the recitation recording of experts as well as the systemization of the recitation process such as providing the reading for five daily prayers and taraweeh prayer. On the other hand, the use of Mobile Quranic Memorization system using RFID technology which is embedded in the student identification card could help in planning a systematic schedule and improve the pace of memorization through the record of memorization performance supported by the system such as location, time, date and user information. Another app known as Quran Companion Application by Quran Academy is a revolutionary-oriented app based on social-led gamification and learning. This app aims at making Quran memorization a fun and easy process through the elements of games, flexible learning environments, students-preference oriented, access to translation and audio as well as guided lesson plans which include the time management plans in achieving the memorization goal via the application.

Nowadays, the traditional methods are not considered as old-fashioned anymore as their functionality is coupled with recent technology. Siddiqui and Muntjir (2017) promoted the 
concept of smart learning as the base platform in introducing the use of smart pens and papers which are built with micro-USB connecting port, Bluetooth and Wifi feature. This combination of printed and digital content allows users to write the information as if using a normal ball pen, with the advantage that the devices would record everything that has been written. Educational strategies in Quran memorization such as listening, reading, verse repetition techniques, testing and writing could now be applied through technology, thus becoming more effective. Maintaining the teaching presence (Baharudin et al., 2018; Nasir, et al., 2018a) and social presence (Nasir, et al., 2018b) could also support the Quran memorization via online learning.

\section{Discussion}

Based on the review of literature conducted, this study has found various memory strategies that could be applied in improving the Quran memorization, which as well could bring positive effects on the self-performance. However, this study also found that less attention is given on developmental type of study which could be recommended for future research. Memory strategies in memorizing the Quran require specific strategies that are different from the common strategies used in language and psychology such as using mnemonic techniques, imagination, narrative strategies in organizing information and so on. Some memory strategies such as narrative strategies in organizing information and mental imagination strategies are not appropriate to be applied in Quran memorization as Alyami et al. (2019) found a significant negative relationship between both strategies with the students' grades in Quran learning, but showed a significant positive relationship for other strategies such as mental practice strategy. Therefore, special strategies in memorizing the Quran should be noted which include paying attention to the letters and correct pronunciation according to the law of tajweed as commanded by Allah in surah al-Muzzammil verse 4 and al-Qiaamah verse 16 to 19, because even one letter of error could lead to different meanings and deviations. Similarly, Salleh et al. (2018) suggested that the tahfiz students could learn the knowledge of tajweed theoretically and applied the knowledge learnt in memorizing the Quran.

Paying attention to the verses of the Quran, the repetition techniques and scheduling memorization are crucial in determining the success of completing the whole Quran. The memorization systems such as the Othman Turkey Method, the Pakistan and India have their own advantages in improving the performance of Quran memorization which are recommended to be practiced by teachers and students. The skills of the Quran such as reading, tajwid, understanding the meaning and evaluating it could further be enhanced through the use of modern technology. Besides, among the other strategy that need to give proper attention are on the markers in mutasyabihah verses and understanding the meaning of the verses through the class teaching. By applying this idea, it could eventually help to overcome the issue of difficulty in mastering the verses among the Hafiz (Quran memorizer).

Another crucial matter that should be taken into consideration is the schedule or the management of memorization as Anwar (2019) found that the memorization of the students has improved, they become more disciplined and the time is wisely utililzed when the muroja'ah (repetition class) schedule is implemented in the learning of Quran. Hence, Anwar (2019) proposed several steps in repetition method to support the quality of memorization which is the Rote method. This method begins with the bin-nadhar reading (by looking at the writing 
manuscripts), followed by the attempts of memorizing without looking at the manuscripts with at least three times of repetition for one sentence until fluency is achieved. Then, the memorization continues with the following verses using the same steps as previous verses until all the verses have been memorized. Finally, the memorization of all the verses will be repeated under the supervision of the instructor within the period of one day. The same method will then continue for new set of memorizations on the following days. Based on the findings by Yaacob et al. (2019), appropriate preparation during the Quran memorization which includes a conducive place, an appropriate time for memorization; before Subuh prayer and in between Maghrib and Isyak prayer and suitable memorization techniques are among the elements considered in achieving high memory performance. Yaacob et al. (2019) also outlined the spiritual preparation before memorizing the Quran which begins with pure intention and strong determination to memorize all 30 chapters of the Quran, having high confidence towards Allah that He would ease the process of memorization and practice good manners towards Allah, the Prophet Muhammad SAW and his Sunnah, knowledge and the teachers, parents as well as all His creatures in this world.

Another technique promoted by Yaacob et al. (2019) in memorizing the Quran especially in remembering the number of verses, pages, surahs and chapters is by using fingers which represent the number of verses being memorized. For example, the first verse of surah AlBaqarah is represented by the thumb, the use of index finger for the second verse, the use of middle finger for the third verse, the ring finger for the fourth verse and the fifth verse is represented by the pinky. Then, the following verses will then continue using another round of fingers to represent verse number six to ten and also applied on memorizing the next verses as well. Furthermore, consistent repetition are also another crucial element in the success of Quran memorization as discussed by Yaacob et al. (2019). Memorizing the Quran does not only limit to conventional methods but also supported with the use of technology which is developed with various functions and combined with murajaah method such as Quran Companion Application. This is supported by Aziz et al. (2019) that modern technological methods almost meet all categories which include monitoring and management in memorization scheduling, easy communication, element of gamification and motivation in completing the Qur'an memorization as compared to conventional methods.

Nonetheless, the aspects of emotional, self-motivation, willingness as well as surroundings should also be taken into account as these indirectly affect the memory performance (Herrmann et al., 2002). Besides, Herrmann et al. (2002) suggested that a systematic record in regards to memory task should be created in order to ensure that the individual could focus on his memory performance as well as identify the ability related to tasks and memory strategies which could be further improved and lead to effective mastery. In the aspect of technology development, Tsortanidou et al. (2017) in promoting Adaptive Educational Hypermedia Systems (AEHS) models stated that technology needs to have user-modeling or student-oriented features that take into account individual differences and be adapted to everchanging user demands in contexts such as capabilities, interest, preferences, knowledge, skills and more. 


\section{Conclusion}

In conclusion, the internal and external memory strategies in Quran memorization outlined throughout this study could be applied by teachers and students, apart from other modern educational strategies in order to improve the quality of memorization. Through the use of modern technology, it could further enhance the memorization quality as various Quran mobile applications are embedded with elements of visual, auditory, gaming, quiz, evaluation and others. Nonetheless, the aspects of emotional, self-motivation as well as surroundings should also be taken into account as these indirectly affect the memory performance.

Memorization is not an old-fashioned strategy, instead it is the foundation in the teaching and learning process in which one could not apply the knowledge gained if one could not memorize well. A strong memory could widen the potential of cognitive capabilities which include speedy development of knowledge, (Klemm, 2007). Based on the concept of memory, the fundamental in memorizing the Quran is through the medium of short-term memory in which it holds the information gained from the sensory memory (input) such as learning the verses of the Quran and later this information will be stored in the long-term memory (by meaning) which then followed by the memory retrieval in order to practice the Quran. This study emphasizes the internal and external strategies as these strategies have been proved in boosting the memorization of the Quran, thus act as a guidance on educational strategies in improving the quality of Quran memorization which would eventually upgrade the teaching and learning of the Quran.

Besides, this study also found various descriptive research related to the Quran memorization in the IEEEXplore database. Among the prominent field of discussion includes the application of the Quran memorization system, techniques in memorizing the Quran as well as several experimental research on the development of technology in enhancing the memorization of the Quran. These findings are believed to be beneficial for the researchers to make references in surveying for the latest memory strategies in memorizing the Quran. Nevertheless, the findings in this study suggest that the future development of technology, activities, modules and learning for the purpose of Quran memorization could consider applying the internal and external strategies in order to boost maximum potential memory performance. Besides, this study also recommends that future developmental-type of research could be further explored for the success of the tahfiz institution. Suggestion is also proposed for the experimental research to test on the effectiveness of the aforementioned strategies in this study towards the memory performance as well as their effects on the achievement in the teaching and learning of the Quran.

\section{Acknowledgement}

This paper and the research would not have been possible without the exceptional support from my dedicated supervisors, M. Khalid M. Nasir and Khadijah Abdul Razak. Their enthusiasm, knowledge and exacting attention to details have been an inspiration on keeping my work on track until the publication of this paper. The authors would also like to express special gratitude to the Faculty of Education, Universiti Kebangsaan Malaysia (UKM) and the team members under the project code GG2019-021. 
INTERNATIONAL JOURNAL OF ACADEMIC RESEARCH IN PROGRESSIVE EDUCATION AND

DEVELOPMENT

Vol. 9, No. 2, 2020, E-ISSN: $2226-6348$ @ 2020 HRMARS

\section{About the Authors}

N. Hashimah A. Shukri is a Master's student, Faculty of Education, National University of Malaysia, 43600 UKM, Bangi Selangor, Malaysia. Her research interests are The Relationship of Motivational Factors with Students' Attitudes in Memorizing the Quran.

M. Khalid M. Nasir is a corresponding author, media coordinator, and a senior lecturer, Centre Department of Innovation in Teaching \& Learning, Faculty of Education, National University of Malaysia, 43600 UKM, Bangi Selangor, Malaysia. His research interest is in Computer Education, Educational Technology, Instructional Technology, Community of Inquiry (Col) in Online learning.

Khadijah Abdul Razak is a Senior Lecturer Centre of Community Education \& Wellbeing, Faculty of Education, National University of Malaysia, 43600 UKM, Bangi Selangor, Malaysia. Her research interests include Educational Philosophy and Islamic Education.

\section{References}

Abbott, K. N., Arnott, C. K., Westbrook, R. F., \& Tran, D. M. D. (2019). The effect of high fat, high sugar, and combined high fat-high sugar diets on spatial learning and memory in rodents: A meta-analysis. Neuroscience \& Biobehavioral Reviews. 107, 399-421. https://doi.org/10.1016/j.neubiorev.2019.03.018

Abdullah, M. H., Aziz, Z. A., Rauf, R. H. A., Shamsudin, N., \& Latiff, R. A. (2019). TeBook A Mobile Holy Quran Memorization Tool. (2019). 2nd International Conference on Computer Applications \& Information Security (ICCAIS) (pp. 1-6). Riyadh, Saudi Arabia. https://doi.org/10.1109/CAIS.2019.8769472

Almosallam, E., Alawadh, M. A, Alhasani, R. S., Almansour, S. M., Altamimi, W. A., \& Altujjar, Y. R. (2015). ITQAN: A Mobile Based Assistant for Mastering Quran Memorization. (2015). Fifth International Conference on e-Learning (ECONF), 18-20 October (pp. 349-352). Manama, Bahrain. https://doi.org/10.1109/ECONF.2015.42

Alyami, I., Alsharif, S., Chipchase, S., \& Pfeffer, K. (2019). The Use of Memory Strategies Among Adolescents in Saudi Arabian Middle Schools. International Journal of Humanities, Arts and Social Sciences. 5(3), 117-127. https://doi.org/10.20469/ijhss.5.20005-3

Anwar, M. A. (2019). Revitalizing the Method of Repetition in the Recitation of the Qur'an. ISTAWA: Jurnal Pendidikan Islam (IJPI). 4(2), 95-100.

http://dx.doi.org/10.24269/ijpi.v2i1.364

Arif, S. (2005). Al-Qur'an, Orientalisme dan Luxenberg. Jurnal Akidah \& Pemikiran Islam. 6(1), 5576.

Ariffin, S., Abdullah, M., \& Ahmad, K. (2016). Implementation of Othman method on memorization the Quran: A Study in Sulaymaniyyah Institute Malaysia. 16th International Conference on Business Economics, Social Science \& Humanities- BESSH-2016, 22 - 23 February (pp. 1-10). China, Beijing.

Aziz, M. M., Abdullah, W. M., Ahmad, A. M., Mushim, M. A. A., \& Shahrudin, M. S. (2019). Comparison between Conventional Method and Modern Technology in Al-Qur'an Memorization. International Journal of Recent Technology and Engineering (IJRTE). 8(1), 289-294. 
INTERNATIONAL JOURNAL OF ACADEMIC RESEARCH IN PROGRESSIVE EDUCATION AND

DEVELOPMENT

Vol. 9, No. 2, 2020, E-ISSN: $2226-6348$ @ 2020 HRMARS

Baharudin, H., Nasir, M. K. M., Yusoff, N. M. R. N., \& Surat, S. (2018). Assessing Students' Course Satisfaction with Online Arabic Language Hybrid Course. Advanced Science Letters. 24, 350-352. https://doi.org/10.1166/asl.2018.12005

Banikowski, A. K., \& Mehring, T. A. (1999). Strategies to Enhance Memory Based on BrainResearch. Focus on Exceptional Children, 0015511. 32(2), 1-16. https://doi.org/10.17161/fec.v32i2.6772

Chen, W. (2019). Does More Sleep Time Improve Memory? Evidence for the Middle-Aged and Elderly. American Journal of Health Education. 50(6), 366-373. https://doi.org/10.1080/19325037.2019.1662859

Frankenmolen, N. L., Overdorp, E. J., Fasotti, L., Claassen, J. A. H. R., Kessels, R. P. C., \& Oosterman, J. M. (2018). Memory Strategy Training in Older Adults with Subjective Memory Complaints: A Randomized Controlled Trial. Journal of the International Neuropsychological Society 2018. 24(10): 1110-1120. https://doi.org/10.1017/S1355617718000619

Gómez-Pinilla, F. (2008). Brain foods: the effects of nutrients on brain function. Nature Reviews Neuroscience. 9, 568-578. https://doi.org/10.1038/nrn2421

Herrmann, D., Raybeck, D., \& Gruneberg, M. (2002). Improving Memory and Study Skills: Advances in Theory and Practice. Germany: Hogrefe \& Huber Publishers.

Jamieson, M., Cullen, B., McGee-Lennon, M., Brewster, S., \& Evans, J. (2017). Technological memory aid use by people with acquired brain injury. Journal Neuropsychological Rehabilitation an International Journal. 27(6), 919-936.

Klemm, W. R. (2007). What Good Is Learning If You Don't Remember It? The Journal of Effective Teaching. 7(1), 61-73.

Lineweaver, T. T., Horhota, M., Crumley, J., Geanon, C. T., \& Juett, J. J. (2018). Age differences in perceptions of memory strategy effectiveness for recent and remote memory. Journal Aging, Neuropsychology, and Cognition: A Journal on Normal and Dysfunctional Development. 25(2), 146-166. https://doi.org/10.1080/13825585

Loprinzi, P. D., Blough, J., Ryu, S., \& Kang, M. (2019). Experimental effects of exercise on memory function among mild cognitive impairment: systematic review and meta-analysis. Journal the Physician and Sports medicine. 47(1), 21-26.

https://doi.org/10.1080/00913847.2018.1527647

May, C., \& Einstein, G. (2013). MEMORY A Five-Day Unit Lesson Plan for High School Psychology Teachers. America: Teachers of Psychology in Secondary Schools (TOPSS) of the American Psychological Association.

McCormick-Huhn, J. M., Bowman, C. R., \& Dennis, N. A. (2017). Repeated study of items with and without repeated context: aging effects on memory discriminability. Journal Memory. 26(5), 603-609. https://doi.org/10.1080/09658211.2017.1387267

Musa, M. G., Yusop, M. H. N., Sopee, M. M. M., \& Ali, N. A. M. (2018). I-tasmik Mobile Platform - Enabling Tahfiz Student to Memorize Al-quran Independently. International Conference on Information and Communication Technology for the Muslim World (ict4m), 23-25 July (pp.24-29). Kuala Lumpur, Malaysia. Doi: https://doi.org/10.1109/ict4m.2018.00014 
Nasir, M. K. M., Surat, S., Maat, S. M., Abd Karim, A., \& Daud, M. Y. (2018a). Confirmatory Factor Analysis on the Sub-Construct of Teaching Presence's in the Community of Inquiry. Creative Education. 9, 2245-2253. https://doi.org/10.4236/ce.2018.914165

Nasir, M. K. N., Mansor, A. Z., and Rahman, M. J. A. (2018b). Measuring Malaysian online university student social presence in online course offered. Journal of Advanced Research in Dynamical and Control Systems. 10(12), 1442 - 1446.

Perna, R., \& Perkey, H. (2016). Internal Memory Rehabilitation Strategies in the Context of Postacute Brain Injury: A Pilot Study. International Journal of Neurorehabilitation. 3(1), 2-5. https://doi.org/10.4172/2376-0281.1000199

Siddiqui, A. T., \& Muntjir, M. (2017). An Approach to Smart Study using Pen and Paper Learning. International Journal of Emerging Technologies in Learning (iJET). 12(5), 117-127. https://doi.org/10.3991/ijet.v12i05.6798

The State of Queensland. (2017). Abios, using Memory Strategies after Brain Injury [fact sheet]. Retrieved april 1, 2020 from https://www.health.qld.gov.au/_data/assets/pdf_file/0036/671877/memory_strategie s_fsw.pdf.2

Tsortanidou, X., Karagiannidis, C., \& Koumpis, A. (2017). Adaptive Educational Hypermedia Systems based on Learning Styles: The Case of Adaptation Rules. International Journal of Emerging Technologies in Learning (iJET). 12(5), 150-168. https://doi.org/10.3991/ijet.v12i05.6967

Yaacob, M. T., Suratman, M. N., Shuib S., Samsungei, M. A., Azali, M. F., Manaf, A. J. A., \& Abdullah, I. (2019). Kaedah Hafazan al-Quran Model Malaysia Teras Panduan Penghafaz Al-Quran. Selangor: Darul Quran JAKIM.

Yusuf, S. A. M., Noh, M. A. C., \& Razak, K. A. (2019). Tahfiz Teachers Ability in Teaching of the Subject Hifz Quran in Implementing Integrated Curriculum Tahfiz (KBT) Secondary Schools. International Journal of Academic Research in Business and Social Sciences. 9(52), 836 - 850. https://doi.org/10.6007/IJARBSS/v9-i5/6010 